ISSN 1027-5495. Functional Materials, 24, No.2 (2017), p. 328-334

doi:https://doi.org/10.15407/fm24.02.328

(C) 2017 - STC "Institute for Single Crystals"

\title{
Experimental study of the salt solution erosing influence on strength of concrete with recycled coarse aggregate
}

\author{
Liu Faming ${ }^{1}$, Zhao Lisha ${ }^{2}$, Yang Bin ${ }^{1}$ \\ ${ }^{1}$ School of Resources and Civil Engineering, \\ Suzhou University, Suzhou 234000, China \\ ${ }^{2}$ School of Mathematics and Statistics, Suzhou University, \\ Suzhou 234000, China
}

Received December 10,2016

\begin{abstract}
There are carried out the experimental study of the loss of the recycled concrete's strength depending on the recycled coarse aggregate substitution ratio, quantity of the fly ash and age of the concrete through investigation of the concrete's compressive strength. It is shown that compared with natural gravel, the recycled coarse aggregates accumulate damages at crushing process and have a lot of micro cracks. In addition, the surface of gravel is wrapped in porous adhesive mortar which provides corrosion resistance of concrete deterioration. With the amount of recycled coarse aggregate increasing, the compressive strength of recycled concrete decreases. The addition of fly ash, which creates a compaction effect, helps improve the erosion resistance of recycled concrete. It is shown that positive effect of aging of recycled concrete is significantly higher than negative effect of salt solution erosion, so with time the strength of recycled concrete is increased.

Keywords: Salt solution, recycled coarse aggregate, coarse aggregate substitution rate, compressive strength.

Проведено экспериментальное исследование потери прочности переработанного бетона в зависимости от коэффициента замены переработанного крупного наполнителя, количества золы-уноса и возраста бетона путем исследования силы сжатия бетона. Показано, что по сравнению с природным гравием, переработанные грубые наполнители имеют много микротрещин, образующихся при дроблении. Кроме того, поверхность гравия покрыта пористым клеевым раствором, который обеспечивает коррозионную стойкость к разрушению бетона. С увеличением количества переработанного крупнозернистого наполнителя прочность на сжатие переработанного бетона уменьшается. Добавление золы-уноса, которая создает эфрфект уплотнения, помогает усилить эрозионную устойчивость переработанного бетона. Было показано, что положительный эффрект старения переработанного бетона значительно выше, чем отрицательный эффрект эрозии солевого раствора, поэтому с возрастом прочность переработанного бетона увеличивается.
\end{abstract}

Експериментальне дослідження впливу ерозійного впливу солей на міцність бетону з переробленим великим наповнювачем. Лю Фалін, Чжао Лища, Ян Бінь

Проведено експериментальне дослідження втрати міцності переробленого бетону в залежності від коефіціента заміни переробленого великого наповнювача, кількості золивинесення та віку бетону шляхом дослідження сили стиснення бетону. Показано, що в порівнянні з природним гравіем, перероблені грубі наповнювачі мають багато мікротріщин, що утворюються при дробленні. Крім того, поверхня гравію покрита пористим клейовим розчином, який забезпечуе корозійну стійкість до руйнування бетону. Зі збільшенням кількості переробленого крупнозернистого наповнювача міцність на стиск переробленого бетону зменшуеться. Додавання золи-винесення, яка створюе ефект ущільнення, допомагає посилити ерозійну стійкість переробленого бетону. Було показано, що позитивний ефект старіння переробленого бетону значно вище, ніж негативний ефект ерозії сольового розчину, тому з віком міцність переробленого бетону збільшуеться. 


\section{Introduction}

With the rapid development of economy and city construction expanding, the scale of construction waste generated every year account for $30 \% \sim 40 \%$ of the total city garbage, it has become the main source of city garbage [1]. The construction waste composition have a lot of species, concrete proportion is the highest among this kind of waste. Traditional processing way of construction waste was mainly landfill or stockpiling, it causes a series of questions about land occupation and environment pollution, construction waste recycling rate is very low. In recent years, scholars from various countries on the sustainable utilization of construction waste were studied. Such as Qiuyi $\mathrm{Li}[2]$ had improved aggregate shape and removed hardened mortar of recycled aggregate surface adhesion, achieve the goal of improve aggregate performance. Yi-bo Yang[3] had putted forward technology for waste concrete all preparation for recycled fine aggregate, it overcomes the high cement stone content which causes high bibulous rate in traditional recycled fine aggregate. Eguchi K[4] had studied the shrinkage of recycled concrete based on the theory of composite. It is pointed out that larger drying shrinkage deformation and lower elastic modulus of recycled aggregate make recycled concrete drying shrinkage is bigger.

Reinforced concrete structure in marine environment has great influenced by the erosion effect of chlorine salt. However, the chloride resistant performance of recycled concrete less studied in recent years. There are have many determination methods and indexes of recycled concrete durability, salt solution effect on the properties of recycled concrete is an important aspect of durability evaluation. Improve the chlorine salt resistance of recycled concrete will protect the reinforcing steel bar is not easy to rust and construction waste recycling[5]. In addition, the recycled aggregate can effectively alleviate the problem of sand shortage, and also effectively reduce construction waste emissions. It is the only way to realize sustainable development of construction industry.

\section{Testing raw material and testing program}

\subsection{Testing Raw Material}

(1) Cement: ordinary Portland cement produced by Huaibei Songshan cement co., LTD, strength grade 42.5 . The main physical performance indexes as indicated in Table 1.

(2) Fly ash: Grade II ash produced by Anhui Huainan Luoneng power generation co., LTD, the main physical performance indexes as indicated in Table 2.

(3) Fine aggregate: the main physical performance indexes of natural sand as indicated in Table 3.

Table 1. The Main Physical Performance Indexes of Cement

\begin{tabular}{|c|c|c|c|c|c|c|c|}
\hline \multirow{2}{*}{$\begin{array}{c}\text { Fineness } \\
1 \%\end{array}$} & \multirow{2}{*}{$\begin{array}{c}\text { Water requirement } \\
\text { of normal } \\
\text { consistency, } / \%\end{array}$} & \multicolumn{2}{|c|}{ Setting time /min } & \multicolumn{2}{|c|}{$\begin{array}{c}\text { Compressive } \\
\text { strength } / \mathrm{MPa}\end{array}$} & \multicolumn{2}{c|}{$\begin{array}{c}\text { Flexural } \\
\text { strength } / \mathrm{MPa}\end{array}$} \\
\cline { 3 - 8 } & & $\begin{array}{c}\text { Initial } \\
\text { setting }\end{array}$ & $\begin{array}{c}\text { Final } \\
\text { setting }\end{array}$ & $3 \mathrm{~d}$ & $28 \mathrm{~d}$ & $3 \mathrm{~d}$ & $28 \mathrm{~d}$ \\
\hline 0.8 & 27 & 180 & 320 & 23.7 & 46.6 & 4.5 & 8.7 \\
\hline
\end{tabular}

Table 2. The main physical performance in

dexes of fly ash (\%)

\begin{tabular}{|c|c|c|c|}
\hline Fineness & $\begin{array}{c}\text { Water } \\
\text { demand ratio }\end{array}$ & Ignition loss & $\mathrm{SO}_{3}$ content \\
\hline 18.5 & 93 & 2.3 & qualified \\
\hline
\end{tabular}

TABLE III. The Main Physical Performance Indexes of Natural Sand

\begin{tabular}{|c|c|c|c|c|c|c|}
\hline Name & $\begin{array}{c}\text { Fineness } \\
\text { modulus }\end{array}$ & $\begin{array}{c}\text { Apparent den- } \\
\text { sity } \\
\text { /kg.m-3 }\end{array}$ & $\begin{array}{c}\text { Bulk den- } \\
\text { sity } \\
\text { /kg.m-3 }\end{array}$ & $\begin{array}{c}\text { Water de- } \\
\text { mand ratio }\end{array}$ & $\begin{array}{c}\text { Strength } \\
\text { ratio }\end{array}$ & Evaluation \\
\hline $\begin{array}{c}\text { Natural } \\
\text { sand }\end{array}$ & 2.7 & 2532 & 1376 & 1.00 & 1.00 & $\begin{array}{c}\text { II area medium } \\
\text { sand }\end{array}$ \\
\hline
\end{tabular}


Liu Faming et al. / Experimental study of the salt solution ...

Table 4. The main physical performance indexes of recycled coarse aggregate and natural gravel

\begin{tabular}{|c|c|c|c|c|c|}
\hline \multicolumn{2}{|c|}{ Name } & $\begin{array}{c}\text { Apparent density } \\
\text { kg.m }{ }^{-3}\end{array}$ & $\begin{array}{c}\text { Needle content } \\
\%\end{array}$ & $\begin{array}{c}\text { Bibulous rate } \\
\%\end{array}$ & $\begin{array}{c}\text { Crush index } \\
\%\end{array}$ \\
\hline \multirow{2}{*}{$\begin{array}{c}\text { Recycled coarse } \\
\text { aggregate }\end{array}$} & After first break & 2409 & 7.6 & 2.5 & 17.6 \\
\cline { 2 - 6 } & After plasticed & 2437 & 5.4 & 1.9 & 14.3 \\
\hline \multicolumn{2}{|c|}{ Natural gravel } & 2472 & 6.7 & 1.8 & 12.1 \\
\hline
\end{tabular}

Table 5. The mix ratio of recycled coarse aggregate concrete

\begin{tabular}{|c|c|c|c|c|c|c|c|}
\hline \multirow[b]{2}{*}{ Group } & \multirow[b]{2}{*}{ Water } & \multirow[b]{2}{*}{ Cement } & \multirow[b]{2}{*}{ Fly ash } & \multicolumn{2}{|c|}{ Recycled Coarse Aggregate } & \multirow[b]{2}{*}{$\begin{array}{c}\text { Natural } \\
\text { gravel }\end{array}$} & \multirow[b]{2}{*}{$\begin{array}{l}\text { Natural } \\
\text { sand }\end{array}$} \\
\hline & & & & $\begin{array}{c}\text { Substitution } \\
\text { rate } \%\end{array}$ & Content & & \\
\hline SJ1 & \multirow{7}{*}{200} & 400 & 0 & 0 & 0 & 1187 & \multirow{7}{*}{668} \\
\hline SJ2 & & 340 & 60 & 0 & 0 & 1187 & \\
\hline SJ3 & & 400 & 0 & 100 & 1187 & 0 & \\
\hline SA1 & & 340 & 60 & 30 & 356 & 831 & \\
\hline SA2 & & 340 & 60 & 60 & 712 & 475 & \\
\hline SA3 & & 340 & 60 & 80 & 950 & 237 & \\
\hline SA4 & & 340 & 60 & 100 & 1187 & 0 & \\
\hline
\end{tabular}

(4) Coarse aggregate: Use jaw crusher to break building material laboratory waste cube concrete whose compressive strength are $30 \sim$ $40 \mathrm{MPa}$ at first, get recycled coarse aggregate by fully dried, using particle shaping machine for plasticing. Next screened with $4.75 \mathrm{~mm}$ and more than $4.75 \mathrm{~mm}$ particles are recycled coarse aggregate which after plasticed. Natural coarse aggregate are natural gravel. The main physical performance indexes of recycled coarse aggregate and natural gravel as indicated in Table IV.

\subsection{Testing program}

Sand content, gravel content and test method refers to Standard for Technical Requirements and Test Method of Sand and Crushed Stone (or gravel) for Ordinary Concrete (JGJ 52-2006), Recycled Fine Aggregate for Concrete and Mortar (GB/T 25176-2010) and Recycled Coarse Aggregate for Concrete (GB/T 251772010). The strength test specimen of recycled concrete were put into the standard curing room for 28 days, and then put into the salt solution. The compressive strength test of recycled concrete according to different ages erosion. Salt solution were divided into $5 \% \mathrm{NaCl}$, $5 \% \mathrm{NaCl}+5 \% \quad \mathrm{Na}_{2} \mathrm{SO}_{4}$ and $5 \% \quad \mathrm{Na}_{2} \mathrm{SO}_{4}$ which are three different kinds of salt concentration. The test is mainly to replace all of the recycled coarse aggregate or part of the natural gravel. Through testing under fly ash and salt solution erosion dual function effect on the compressive strength of recycled concrete. The water cement ratio of this test is 0.5 .

\subsection{Testing mix ratio}

The testing specimens were used C30 strength grade as the benchmark and were divided into two groups. SA group is recycled coarse aggregate concrete. SA1, SA2, SA3 and SA4 are respectively on behalf of recycled coarse aggregate content account for 30\%, 60\%, $80 \%$ and $100 \%$ of the total coarse aggregate quality. SJ group as the benchmark, SJ1 is not add recycled coarse aggregate and fly ash, SJ2 is not add recycled coarse aggregate but fly ash adding, SJ3 is add 100\% recycled coarse aggregate but without fly ash. Put these specimens into three different types of salt solution immersion, soaking time lasting for half a year. In this time, the compressive strength of recycled concrete specimens had been tested under different ages ( 7 days, 28 days, 60 days, 90 days and 180 days). The mix ratio of recycled coarse aggregate concrete as indicated in Table V.

\section{Testing result and analysis}

\subsection{The compressive strength after salt solution erosion at different ages}

According to Standard for Test Method of Mechanical Properties on Ordinary Concrete (GB/T 50081-2002), The compressive strength of after eroding recycled coarse aggregate concrete which are $150 \mathrm{~mm} \times 150 \mathrm{~mm} \times 150 \mathrm{~mm}$ cube specimens as calculated in formula(1):

$$
f_{c}=\frac{F}{A}
$$


Table 6. The compressive strength results of recycled coarse aggregate concrete

\begin{tabular}{|c|c|c|c|c|c|}
\hline \multirow{2}{*}{$\begin{array}{c}\text { Speci- } \\
\text { men } \\
\text { number }\end{array}$} & \multicolumn{5}{|c|}{$\begin{array}{c}\text { Compressive strength after salt solu- } \\
\text { tion erosion, } \mathrm{MPa}\end{array}$} \\
\cline { 2 - 6 } & $7 \mathrm{~d}$ & $28 \mathrm{~d}$ & $60 \mathrm{~d}$ & $90 \mathrm{~d}$ & $180 \mathrm{~d}$ \\
\hline SJ1-1 & 33.4 & 36.6 & 37.2 & 37.7 & 40.1 \\
\hline SJ1-2 & 32.3 & 35.9 & 36.4 & 37.3 & 39.2 \\
\hline SJ1-3 & 32.8 & 36.2 & 37.9 & 37.8 & 40.4 \\
\hline SJ2-1 & 35.2 & 38.5 & 39.4 & 39.7 & 42.6 \\
\hline SJ2-2 & 33.7 & 36.4 & 37.1 & 38.2 & 40.9 \\
\hline SJ2-3 & 35.8 & 39.2 & 40.6 & 41.4 & 42.7 \\
\hline SJ3-1 & 28.4 & 28.7 & 29.6 & 31.2 & 32.1 \\
\hline SJ3-2 & 26.4 & 27.2 & 29.3 & 30.8 & 31.4 \\
\hline SJ3-3 & 29.5 & 30.3 & 30.5 & 30.9 & 32.3 \\
\hline SA1-1 & 34.3 & 33.6 & 35.5 & 34.6 & 38.8 \\
\hline SA1-2 & 32.2 & 34.6 & 34.4 & 36.2 & 37.9 \\
\hline SA1-3 & 33.7 & 35.2 & 37.6 & 37.7 & 40.5 \\
\hline SA2-1 & 30.8 & 32.1 & 33.4 & 32.9 & 34.8 \\
\hline SA2-2 & 29.1 & 30.6 & 32.2 & 31.6 & 33.5 \\
\hline SA2-3 & 31.2 & 33.4 & 32.8 & 35.6 & 36.1 \\
\hline SA3-1 & 28.4 & 29.7 & 31.8 & 32.7 & 33.3 \\
\hline SA3-2 & 29.7 & 30.4 & 30.8 & 31.2 & 33.0 \\
\hline SA3-3 & 30.2 & 31.7 & 32.4 & 31.9 & 34.6 \\
\hline SA4-1 & 29.1 & 30.5 & 31.6 & 32.2 & 33.5 \\
\hline SA4-2 & 28.2 & 29.9 & 30.6 & 30.9 & 32.3 \\
\hline SA4-3 & 30.1 & 32.7 & 34.3 & 33.1 & 35.8 \\
\hline
\end{tabular}

Note: In the table, - 1 means soaking in $5 \% \mathrm{NaCl}$ salt solution, -2 means soaking in $5 \% \mathrm{NaCl}+5 \% \mathrm{Na}_{2} \mathrm{SO}_{4}$ salt solution, -3 means soaking in $5 \% \mathrm{Na}_{2} \mathrm{SO}_{4}$ salt solution.

Where,

$f_{c}$ - the compressive strength of recycled concrete specimens, $\mathrm{MPa}$;

$F$ - the compressive failure load of specimens, N; $A$ - the compression area of each specimen, $\mathrm{mm}^{2}$.

The compressive strength of recycled coarse aggregate concrete after salt solution erosion as indicated in Table 6.

\subsection{Salt solution effects on the com-} pressive properties of recycled coarse aggregate concrete

\subsubsection{Different substitution rate of re-} cycled coarse aggregate

Take the SJ2, SA1, SA2, SA3, SA4 as a batch, then draw the result of the experiment as shown in Figure 1and Figure 2.

It is shown from Fig.(1) and Fig.(2) that when the substitution rate of recycled coarse aggregate increase, no matter what kind of salt solution immersion, the compressive strength of recycled concrete are all decreased obviously. In $5 \% \mathrm{NaCl}$ salt solution erosion after $7 \mathrm{~d}$, the compressive strength of recycled concrete were lost $0.9 \mathrm{MPa}$ and $4.4 \mathrm{MPa}$. $6.8 \mathrm{MPa}$ and $6.1 \mathrm{MPa}$,

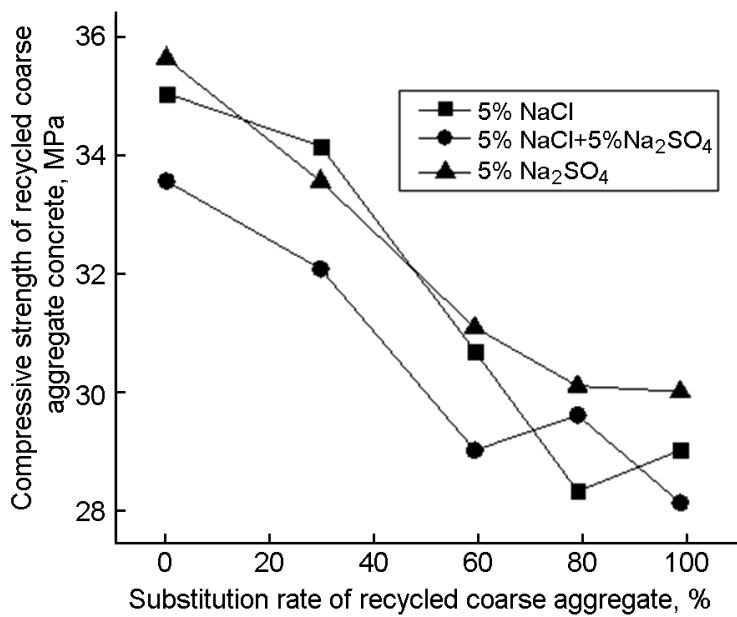

Fig. 1. The relationship between different substitution rate and compressive strength of recycled coarse aggregate $(7 \mathrm{~d})$

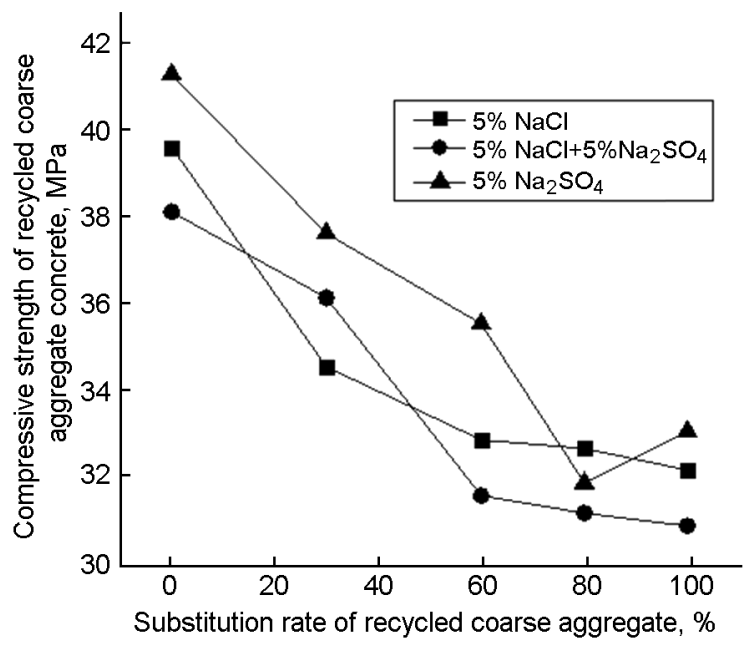

Fig. 2. The relationship between different substitution rate and compressive strength of recycled coarse aggregate (90d)

the loss rate is as high as $19.3 \%$. In $5 \% \mathrm{NaCl}$ salt solution erosion after $90 \mathrm{~d}$, the compressive strength of recycled concrete were lost 6.3MPa, $6.8 \mathrm{MPa}, 7.0 \mathrm{MPa}$ and $7.5 \mathrm{MPa}$, the is as high as $18.9 \%$. Obviously, the higher recycled coarse aggregate substitution rate, the worse salt solution erosion resistance. This is mainly because the cumulative damage of recycled coarse aggregate in crushing process and exist a lot of micro crack. In addition, the surface of gravel are wrapped in porous adhesive mortar [6-7].

When recycled coarse aggregate substitution rate reached $100 \%$, the highest compressive strength of recycled concrete loss. The compressive strength loss rate had reached to $17.3 \%, 16.3 \%$ and $15.9 \%$ respectively. After $90 \mathrm{~d}$ erosion in salt solution, the compressive 


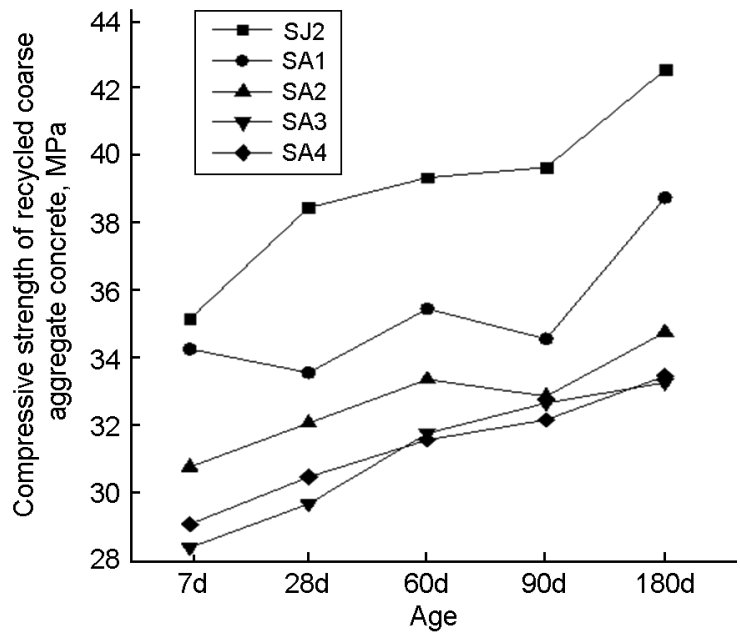

Fig. 3. The compressive strength of recycled concrete in $5 \% \mathrm{NaCl}$ salt solution (1).

strength loss rate had reached to $18.9 \%, 19.1 \%$ and $20.1 \%$. This is mainly because micro crack and defect of adhesive mortar are more obvious when the recycled aggregate replace all natural gravel, so the ability of salt solution erosion resistance had fell sharply.

\subsubsection{Different Ages}

It is shown from Fig. (3), Fig. (4) and Fig. (5) that when recycled concrete age increase, no matter what kind of salt solution immersion, the compressive strength of recycled concrete are all rise obviously. The compressive strength of SJ group specimens after 180 days salt solution immersion increased significantly greater than the other groups, among the increase rate of SJ2-1 group is as high as 21.0\%.This is mainly because natural gravel have smaller porosity and stronger permeability than recycled coarse aggregate. After a long time soaking in salt solution, or in the salt solution can react with cement hydration products and create dilatants, expansive force is greater than concrete tensile strength will lead to concrete cracking [8]. In the long run, concrete strength will gradually decline. The surface of recycled coarse aggregate are wrapped in porous adhesive mortar, these dilatants can't filled fully, so the compressive strength of recycled concrete after immersion is less than ordinary concrete.

It is also shown from Fig. (3), Fig. (4) and Fig. (5) that concrete compressive strength in $5 \% \mathrm{NaCl}+5 \% \mathrm{Na}_{2} \mathrm{SO}_{4}$ is lower than the other kinds of salt solution. In different ages, the compressive strength of SA4-2 had reduced 6.3\%, $8.6 \%, 10.8 \%, 6.6 \%$ and $9.8 \%$ relative to SA $4-3$ group. The compressive strength of SA4-2 had reduced $3.1 \%, 2 \%, 3.2 \%, 4 \%$ and $3.6 \%$ relative to SA4-1 group. By analyzing testing data, we had found that the recycled concrete in chlo-

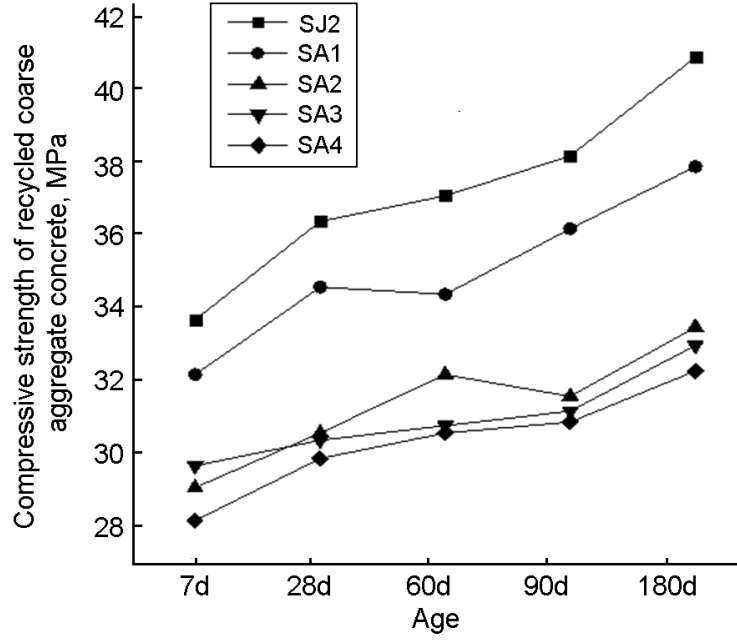

Fig. 4. The compressive strength of recycled concrete in $5 \% \mathrm{NaCl}$ salt solution (2).

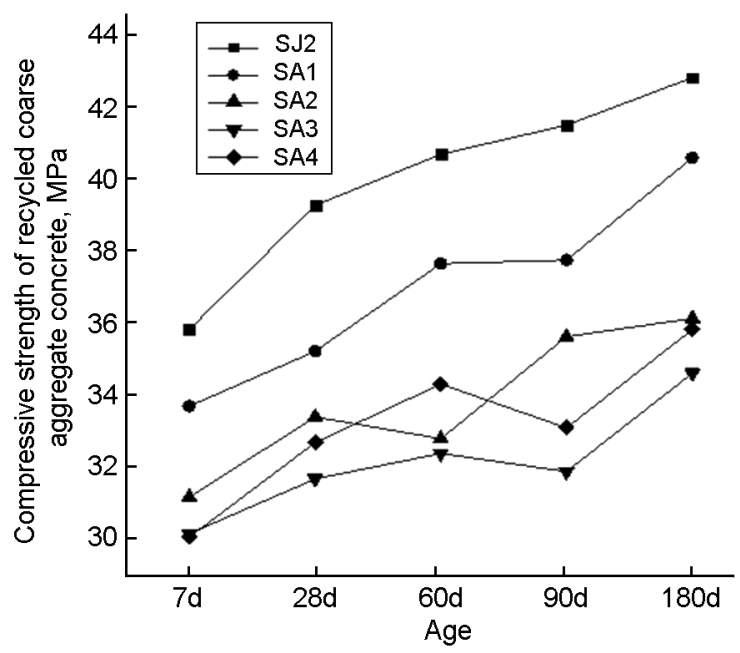

Fig. 5. The compressive strength of recycled concrete in $5 \% \mathrm{NaCl}$ salt solution (3).

ride salt environment erosion degree is more serious than it is in sulfate environment. Two kinds of mixed salt solution is coupling effect on recycled concrete. Mixed salt solution can accelerate recycled concrete erosion degree.

\subsubsection{Fly Ash}

Take the SJ1, SJ2, SJ3, SA4 as a batch, then draw the result of the experiment as shown in Fig. (6), Fig. (7) and Fig. (8).

Through Fig. 6, Fig. 7 and Fig. 8 can be seen, no matter what kind of salt solution immersion, the compressive strength of SJ2 group is highest and SJ3 group is lowest. It can be found that improving the erosion resistance of concrete effectively after fly ash added. For example, the compressive strength of SA4 group specimens which were higher than SJ3 group which without fly ash adding. In $5 \% \mathrm{Na}_{2} \mathrm{SO}_{4}$ 


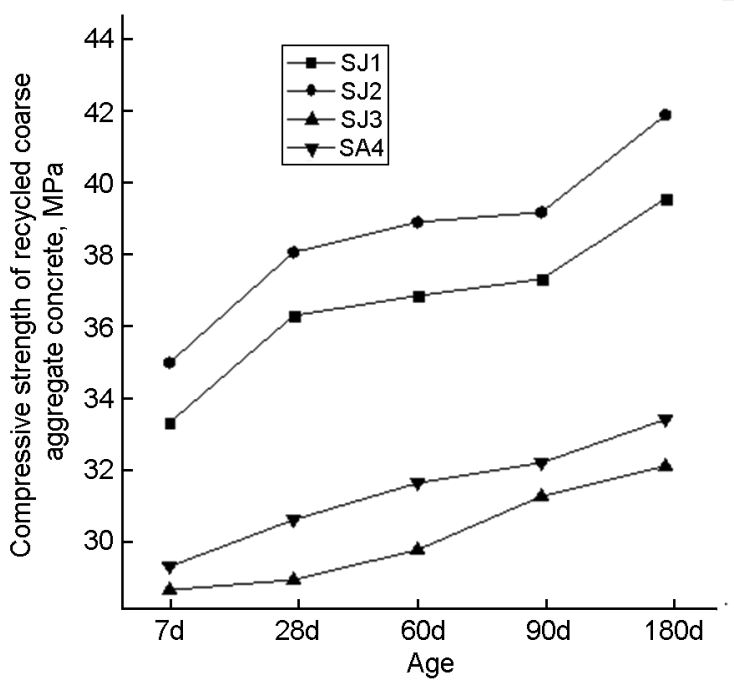

Fig. 6. The compressive strength of recycled concrete in $5 \% \mathrm{NaCl}$ salt solution (4).

salt solution and different ages, the compressive strength of SA4 group had increased 2.0\%, $7.9 \%, 12.5 \%, 7.1 \%$ and $10.8 \%$ relative to SJ3 group. The compressive strength of recycled concrete in $5 \% \mathrm{Na}_{2} \mathrm{SO}_{4}$ is generally larger than other two kinds of salt solution. It is shown that after fly ash substituting partial cement, the sulfate resistance ability of recycled concrete is superior to chloride resistance. This is mainly because the fly ash have played a volcano ash effect, meanwhile filled compaction effect. The recycled concrete is one kind of multicomponent and multiphase complex system, each component material is not easy to achieve together and even. Fly ash powder can be filled between the cement hydration products, so improving the gradation and aperture of recycled concrete cementing material effectively. It makes the cement structure more compaction, blocking the erosive path of chlorine salt and sulfate, so improving the compressive strength of recycled concrete correspondingly[9].

It is not difficult to find that using recycled coarse aggregate to prepare concrete can content strength requirement through data in Table 6 . The recycled concrete strength was decrease little when substitution rate of recycled coarse aggregate at around 30\%. Adding fly ash, the later strength of recycled concrete can at the same level as ordinary concrete. According to the requirement added moderate amount of fly ash or some other active material into concrete in engineering practice, in order to improve the pore structure of recycled concrete [10]. It is appropriated that Substitution rate of recycled coarse aggregate is no more than $30 \%$ of natural gravel.

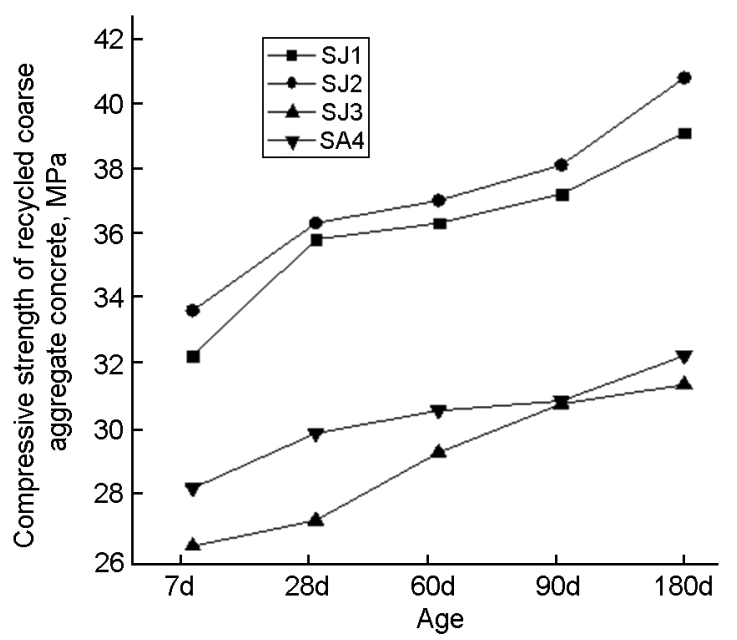

Fig. 7. The compressive strength of recycled concrete in $5 \% \mathrm{NaCl}$ salt solution (5).

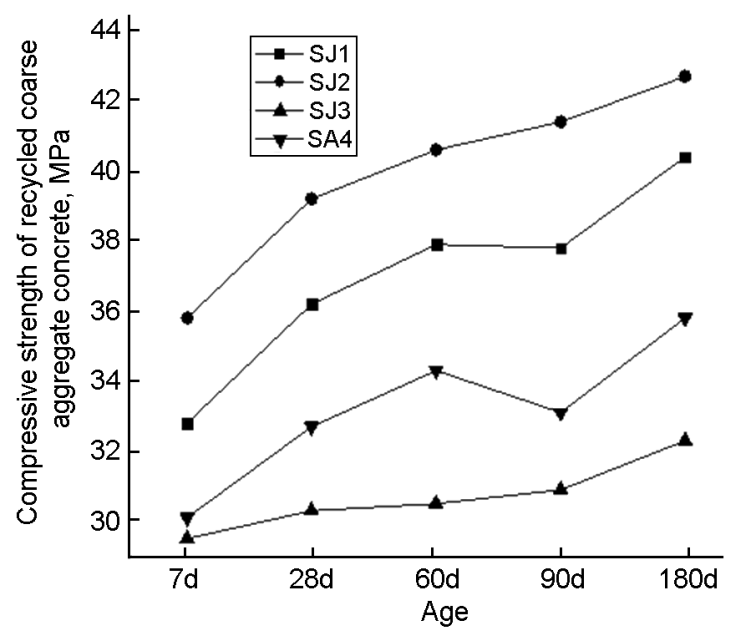

Fig. 8. The compressive strength of recycled concrete in $5 \% \mathrm{NaCl}$ salt solution (6).

\section{Conclusions}

(1) Along with increasing content of recycled coarse aggregate, the compressive strength of recycled concrete is on the decline. Poorer chloride and sulfate resistance of recycled concrete than ordinary concrete. This is because adhesive mortar and damaging stone have negative impact on the durability of recycled concrete.

(2) The addition of fly ash, It can be improve the erosion resistance of recycled concrete effectively because of adding fly ash. This is mainly because the fly ash have played a volcano ash effect, meanwhile filled compaction effect. Blocking the erosive path of harmful substances and making the microstructure of cement stone more compact, so improved the strength of recycled concrete and durability correspondingly. 
(3) Sulfate resistance is superior to chlorine resistance when substituting fly ash for partial cement. The coupling effect of sulfate and chloride salt will accelerate decreasing strength of recycled concrete.

(4) Age impact on developing strength of recycled concrete is higher than salt solution erosion. So the longer time, the higher strength of recycled concrete. But there are have negative effect on strength growing in salt solution environment. This is mainly because after a long time soaking in salt solution, $\mathrm{Cl}$ or $\mathrm{SO}_{4}{ }^{2-}$ in the salt solution can react with cement hydration products and create dilatants, expansive force is greater than concrete tensile strength will lead to concrete cracking, also reduced the strength and durability of concrete. This researchable area needs further validation.

\section{Acknowledgements}

This work is financially supported by key project of natural science foundation of Anhui provincedepartmentofeducation(KJ2016A773). Teaching research project of Suzhou University (szxy2015jy15). The visiting research key project of college young and middle-aged backbone talents(gxfxzd2016264). Quality engineering project of Anhui province (2016ckjh200).

\section{References}

1. Jianzhuang Xiao, Recycled Concrete, Beijing: China Architecture \& Building Press, 2008.

2. Qiuyi Li, Yunxia Li, Chongji Zhu, New Build. Mater., 1, 17, 2006.

3. Yibo Yang, Song Liang, Haihong Mo, et al, J. Funct. Mater., 4, 4157, 2016.

4. Eguchi K, TeranishiK, Narikawa M, J. Struct. Constr.Engin., 1, 17, 2003.

5. Xiaofei Wang, Qingdao Techn. Univ. master thesis, p. 29, 2015.

6. Ting Li, Beijing Jiaotong Univ. master thesis, p. 65, 2013.

7. Xiuliang Huang, Hefei Univ. Techn. master thesis, p. 1, 2013.

8. Xiufang Zhang, Gengxin He, Xiaolong Zhao, Construct. Techn., 40, 60.

9. Xiaoxiao Wang, Xiangdong Shen, China Water Power Press, p.121, 2015.

10. Jun Zhao, Genwei Wang, Sichuan Build Scie, 40, p. 225. 